\title{
Retraction Note: Meeting Abstract: A post-hoc qualitative analysis of real time heads-up pollen counting versus traditional microscopy counting in the environmental exposure unit (EEU)
}

Lisa M Steacy ${ }^{1 *}$, Terry JB Walker ${ }^{1}$, Barnaby Hobsbawn ${ }^{1}$, Jenny Thiele ${ }^{2}$ and Anne K Ellis ${ }^{1,2}$

\section{Retraction}

This meeting abstract [1], published in the Canadian Society of Allergy and Clinical Immunology and AllerGen Abstracts 2014 supplement, has been retracted from Allergy, Asthma \& Clinical Immunology by the authors. The meeting abstract has previously been published in Journal of Allergy and Clinical Immunology [2] and was inadvertently submitted to Allergy, Asthma \& Clinical Immunology as part of the supplement. The authors apologise for any inconvenience that this may have caused.

\section{Author details}

'Allergy Research Unit, Kingston General Hospital, Ontario, Canada.

${ }^{2}$ Department of Medicine, Queen's University, Kingston, Ontario, Canada.

Received: 6 March 2015 Accepted: 6 March 2015

Published online: 17 April 2015

\section{References}

1. Steacy LM, Walker TJB, Hobsbawn B, Thiele J, Ellis AK. A post-hoc qualitative analysis of realtime heads-up pollen counting versus traditional microscopy counting in the environmental exposure unit (EEU). Allergy Asthma Clin Immunol. 2014;10 Suppl 2:A48.

2. Steacy LM, Walker TJB, Hobsbawn B, Thiele J, Ellis AK. A post-hoc qualitative analysis of realtime heads-up pollen counting versus traditional microscopy counting in the environmental

exposure unit (EEU). J Allergy Clin Immunol. 2014;133(2):AB18.

* Correspondence: steacyl@kgh.kari.net

${ }^{1}$ Allergy Research Unit, Kingston General Hospital, Ontario, Canada

Submit your next manuscript to BioMed Central and take full advantage of:

- Convenient online submission

- Thorough peer review

- No space constraints or color figure charges

- Immediate publication on acceptance

- Inclusion in PubMed, CAS, Scopus and Google Scholar

- Research which is freely available for redistribution

Submit your manuscript at www.biomedcentral.com/submit
() Biomed Central 